\title{
Meta
}

Journal des traducteurs

Translators' Journal

\section{Robinson, Douglas (2011): Translation and the Problem of Sway. Amsterdam/Philadelphia: John Benjamins Publishing Company, 227 p.}

\section{Jun Wen et Xiaomeng Duan}

Volume 58, numéro 1, avril 2013

URI : https://id.erudit.org/iderudit/1023821ar

DOI : https://doi.org/10.7202/1023821ar

Aller au sommaire du numéro

Éditeur(s)

Les Presses de l’Université de Montréal

ISSN

0026-0452 (imprimé)

1492-1421 (numérique)

Découvrir la revue

Citer ce compte rendu

Wen, J. \& Duan, X. (2013). Compte rendu de [RoBinson, Douglas (2011): Translation and the Problem of Sway. Amsterdam/Philadelphia: John Benjamins Publishing Company, 227 p.] Meta, 58(1), 252-254.

https://doi.org/10.7202/1023821ar d'utilisation que vous pouvez consulter en ligne. 
connaissait l'existence des esclaves dans l'antiquité, il ne s'est jamais attardé sur leur rôle d'interprètes chez les Ottomans ni sur le fait que Le Livre de Marco Polo fut «très probablement une traduction improvisée» (p. 213) de Rustichello de Pise, qui se trouvait être dans la même cellule que Marco Polo, ou que l'histoire d'Ossian et Le Château d'Otrante de Horace Walpole n'étaient que des pseudo-traductions dont il fallut avouer qu'elles constituaient une supercherie. Notre lecteur se doute que c'est au Tribunal militaire international de Nuremberg que l'on doit la réflexion sur la nécessité et sur les difficultés de la traduction simultanée dans les organismes supranationaux de l'époque et futurs - comme l'UE ou l'ONU. Encore fallait-il le lui rappeler.

Le projet était de taille à décourager bien des spécialistes: les risques de naïvetés et de redites étaient réels, cependant David Bellos a relevé le défi et, grâce à sa longue expérience traductologique et pédagogique, il a réussi dans son entreprise.

MariaCristina Pedrazzini Université Catholique de Milan, Italie

Robinson, Douglas (2011): Translation and the Problem of Sway. Amsterdam/Philadelphia: John Benjamins Publishing Company, 227 p.

As translation theories have evolved to integrate cultural elements over the past decades, the concept of faithfulness to the original or correctness inevitably ceased to be the dominant evaluative standards of particular translation products. The production and reception of translation are increasingly seen as a result of complex governing powers exerted by various aspects of cultural contexts. Those governing powers or pressures have become the focus of present day translation related studies. Among the different works theorizing those pressures, Descriptive Translation Studies are quite successful in describing the pressures driven by the literary norms of target culture and the professional agents, which can be seen as the characterizing the socioeconomic approach. Other theories place more emphasis on describing habitualized interpretation of certain translated products, such as Venuti's discussions on the concept of "interpretant" and Mona Baker's discussions about "narrativity." Translation and the Problem of Sway, authored by Douglas Robinson, makes a further contribution to the effort of theorizing those cultural formed habits and psychological trends along the lines of Venuti and Baker's work, but what makes his work innovative and contributory is the integration of the study of normative and non-normative sways using his own conceptual framework - somatic theory. This book consists of six chapters.

In Chapter 1, Introduction, Translation and Sway (pp. 1-15), the author suggests that "sway" which influences translator's work is defined too narrowly. The translation norms theorized by Toury are merely the "positive" versions of translational sways, which exclude explicit rules and fully subjective idiosyncrasy. Venuti's work on interpretant and Baker's work in narrativity also treat what sways the translator as "bias," which apparently carries a negative meaning. The author suggests, alternatively, to subsume the norms and values we hold most dear and the bias under the same category - "sway." To put the sway in Robinson' words, it is "almost a group dynamic, not typically something that happens inside individual nervous system (p. 9)," and those "sways" that weigh upon the translators' work are the focus of Robinson's book.

In Chapter 2, Lawrence Venuti on the Interpretant (pp. 17-39), the author introduces Venuti's concept of the interpretant and points out that the semiotic terms used by Venuti in this definition are largely depersonalized tend to reduce human creativity to a robotic sense, which is the staple viewpoint of many theorists like Martindale. The author introduces his somatic model of human interaction both to give Venuti's theory more complexity and to refute Martindale's accusation.

In Chapter 3, The Case of Alex. Matson (pp. 41-111), the author conducts a long case study of a single translator, Alex Matson (1888-1972), who spent his childhood in England and adulthood in his native Finland. The author analyses Matson's translations into Finnish of James Joyce's Portrait of the Artist as a Young Man and William Faulkner's Wild Palms and As I Lay Dying, and his translations into English of Aleksis Kivi's 1870 novel Seven Brothers and several works by Aino Kallas and F. E. Sillanpää with the objective of testing Venuti's "formal" interpretant. The case study finds that Matson's awkward English cannot be attributed to a foreignizing attention to the original. It also shows that Venuti's formal interpretant is not valid enough to account for the complexity of translation phenomenon. The author suggests that there are rhetorical interpretants guiding our interactions with other people; that rhetorical interpretants might be divided into logical interpretants (governing structure), pathetic interpretants (governing affective interaction), and ethical interpretants (governing the perception of character); and that Venuti's two types of interpretant, the formal and the thematic, should be seen as subcategories of the logical interpretant. 
In Chapter 4, The Spatiotemporal Dynamic of Foreignization (pp. 113-130), the author focuses on the interactive (rhetorical) spatiotemporal dynamic governing foreignism and points out that Venuti remains vague about his conceptualizations of foreignism. We are never quite sure whether it is built into and stably recognizable in the text in a formalist mode, or an impact on each individual target reader. The clashes between these two orientations are never quite resolved. The author argues that a foreignization translation does not necessarily have a static property and that the lingering traces of objectivism in Venuti's theorization should be banished. The author introduces the concept of "proprioception," a term borrowed from physiology, referring to "a sense that makes us feel our body as our own” (p.116).” Robinson uses it metaphorically as a description of what happens in the reading of translational or other texts to emphasize that for the estranging effect of the foreignization to be complete, the target must proprioceptively assimilate the strange into the familiar. If not, foreignization strategy will have no impact on the readers.

In Chapter 5, Translating Dostoevsky, Theorizing Translation (pp. 131-159), the author conducts another case study, which centers on the rival English translations of Dostoevsky's Brothers Karamazov by Constance Garnett in 1912 and the one by Richard Pevear and Larisa Volokhonsky in 1990. That the translated version by Garnett naturalizes and the one by Pevear and Volokhonsky foreignizes is the interpretation initially held by Emerson and May, then borrowed by Venuti.; However, the author finds that differences between the two versions in terms of degree of foreignization are not as salient as originally thought. Venuti's perception that the two versions differ greatly actually derives from functions of the metathematic interpretant (reliance on authorities) and metaformal interpretant (commitment to agenda). The author further introduces the term "axiological interpretant," which corresponds to an ideological formation according to which the original writer by default is a better writer than translator.

Finally, Chapter 6 Mona Baker on Narratives (pp. 161-187) is devoted to Mona Baker's narrative paradigm for the study of translation. The author pushes the theory further by probing into the core of the narrative, which according to him is interpretant as organized by ideosomatic regimes. This kind of sway can be understood as inchoately channeled through group-norm to impose a certain type of interpretation of experience. The case the author uses to demonstrate his point here is Reagan's rhetorical success, also the success of personal narrative, which is grounded in the American master and public narratives of heroism.

Several advancements over the previous theories centered on translation "norms" have been made in this book.

Firstly, Douglas Robinson traces the problem of defining "norms" narrowly. Instead, he offers the concept of "sway" to bring together discussions of two translational phenomena that have traditionally been considered in isolation, i.e., norms and errors: norms as ideological pressures to conform to the source text, and deviations from the source text as driven by ideological pressures to conform to some extra-textual authority. The integration of these two terms makes a more comprehensive and convincing examination and explanation of translation phenomena possible, which also complies with the consensus that translation studies should develop along a descriptive line without positing concepts such as incorrect or correct translations.

Secondly, the author offers a series of "friendly amendments" to Lawrence Venuti's “interpretant” and Mona Baker's "narrativity" around which the discussion of translational sway is organized. He pushes these two theories further by incorporating his somatic theory, which posits that the circulation of shared evaluative affect through the collective body-becoming-mind of a group constitutes a living and constantly self-adjusting and selfregulating organism. By conducting his analysis under this framework, two problems of the traditional cultural approach to translation studies are resolved to some extent. The somatic theory which allows for the complexity and choices of human behaviors overcomes the tendency characterized by an ideological approach to reduce human creativity to robotic process, and the inclusion of the rhetorical model into the concept of "foreignism" gives readers' responses more attention.

Still, some questions about the author's theory remain unanswered. We wonder whether somatic exchange can suffice to account for the complex process in which the transient emotive associations or certain evaluative inclinations acquire the status of established norms in a certain culture. That is to say, it seems somewhat overly simplifying the process of group-norm acquisition to assume that certain affective feelings become established norms of a certain society simply because their members read and mimetically simulate others' body languages unconsciously, and that this feeling then goes through a process that is first affective, then cognitive, and ultimately reticulates throughout society. There must be other channels through which certain affective associations become collectivized norms other than bodily simulations. The author's work clearly signals a new direction 
of researching into the unconscious process of norm-acquisition, but surely his somatic model cannot be the only explanation though it serves as a starting point for future research.

Jun Wen and Xiaomeng DuAN Beihang University, Beijing, China

Roberto Valdeón, ed. (2010): Translating Information. Oviedo: Ediciones de la Universidad de Oviedo, $218 \mathrm{p}$.

De manera generalizada, tanto en los estudios especializados sobre el tema como en la conciencia de la ciudadanía lega, la globalización se asocia a una disponibilidad ilimitada de información. En la visión imperante, este caudal informativo circula y viaja libremente integrado en un vertiginoso tráfico de enunciados que ignoran o mágicamente salvan fronteras de todo tipo, entre ellas políticas, sociales, culturales, lingüísticas y hermenéuticas. $\mathrm{Y}$, si bien es cierto que en comparación con otras épocas, los medios tecnológicos de la era digital han multiplicado exponencialmente la información que está al alcance de la población, también lo es que, en ese orden postnacional que se asocia a la que Castells denominara "la sociedad red", la información que efectivamente viaja es infinitesimal en comparación con la que se excluye y se descarta, y, sobre todo, que incluso la que inicia su travesía internacional no suele llegar a sus distintos destinos de manera directa, sin escalas ni mediación alguna, sino que, por el contrario, se halla sometida a nuevos y constantes procesos de selección, manipulación, mediación, comprensión y reformulación -traducción en su sentido amplio, en una palabra- sobre los que poco o nada se reflexiona. Sin embargo, son tantos los intereses que hay en juego y de tal calibre las implicaciones ideológicas y políticas que de estos intensos flujos de enunciados se desprenden que urge acometer estudios sobre el fenómeno traslatorio en nuestros días, una urgencia, al menos, más que justificada en virtud la magnitud del fenómeno. Y es que, como ya advirtiera José Lambert de manera visionaria en una serie de trabajos pioneros en analizar el papel y las características de la traducción en la era de la comunicación de masas, aunque suele pasar inadvertida en gran medida, entre otras cosas por cuanto hoy actúa de manera fragmentaria y camuflada, haciéndose pasar por discurso original, la traducción es ubicua en nuestra época. $\mathrm{O}$, como lo formulan autores como Michael Cronin (2003) o Esperanza Bielsa (2005), cabe pensar la globalización como traducción.

El volumen Translating Information, editado por Roberto Valdeón, trata de contribuir a subsa- nar una llamativa falta de reconocimiento del papel actual de la traducción en la circulación internacional de los discursos. Si esta carencia es general en las ramas del saber de las ciencias sociales preocupadas por el fenómeno de la comunicación, donde el omnipresente fenómeno de la traducción pasa por lo general inadvertido, lo cierto es que también en el ámbito propio de los Estudios de Traducción también se echa poca reflexión sobre la actividad traductora en la configuración de la información multinacional. No en vano, en nuestra disciplina, aún aferrada a concepciones marcadamente textualistas de la traducción (como reproducción de $u n$ texto por otro equivalente en otra lengua) heredadas de modelos de explicación del fenómeno traductor gestados en el ámbito de la literatura, los estudios sobre la traducción como actividad discursiva con un papel protagónico en la construcción de la actual esfera pública son, aunque interesantísimos, aún marginales en términos cuantitativos. Por otra parte, si por su temática el volumen resulta relevante y oportuno, el rigor y la solidez de las aportaciones, que de manera generalizada combinan los conceptos de las últimas corrientes teóricas con el análisis descriptivo de textos o procesos reales, lo hacen doblemente interesante.

En el primer capítulo del volumen, "Media, information et traduction à l'ère de la mondialisation", Yves Gambier presenta de manera panorámica e integradora los entresijos, los procesos ocultos, de la diseminación de la información en nuestra era. Con una destacable capacidad para interrelacionar conceptos y extrapolar de manera esclarecedora nociones, conclusiones y ejemplos de diferentes ámbitos, se apuntan los factores y procedimientos implicados en la creación de los discursos dominantes, exposición que se acompaña de una reflexión acerca de las implicaciones de tales prácticas o que da pie a iniciarla. El principal atractivo de este trabajo es que, lejos de limitarse a dar respuesta sobre el funcionamiento de la traducción tanto a nivel macrodiscursivo como microtextual, plantea interesantísimas a la par que inquietantes preguntas, cuyo interés no se restringe únicamente al estudioso de la traducción. De interés específico para los investigadores del tema es la parte final del capítulo, donde se apuntan nuevas perspectivas y líneas de investigación que requieren atención o resultan prometedoras.

El segundo capítulo, “Translating News: A Comparison of Practices in News Agencies", de Esperança Bielsa, presenta un esclarecedor trabajo descriptivo sobre las prácticas traslativas en las agencias de prensa. Además de abordar cuestiones que van desde lo geopolítico hasta lo estrictamente procedimental, el capítulo también se adentra en el análisis de la(s) identidad(es) corporativa(s) 